\title{
Combined support mechanism of rock bolts and anchor cables for adjacent roadways in the external staggered split-level panel layout
}

\author{
Adrian Batugin $^{1} \cdot$ Zhiqiang Wang $^{1,2} \cdot$ Zehua Su$^{2} \cdot$ Shermatova Sayyora Sidikovna $^{1}$
}

Received: 23 April 2020/Revised: 5 August 2020/Accepted: 24 December 2020/Published online: 25 January 2021

(C) The Author(s) 2021

\begin{abstract}
Using the spatial structure of the external staggered split-level panel layout, a combined support technology for adjacent roadways was developed and analyzed for a rock bolt and anchor cable mechanism. The influence of the side rock bolt and anchor cable parameters on the mechanical properties of the anchorage body and the support stress distribution of the lateral coal body were revealed using the FLAC $^{3 \mathrm{D}}$ software. The optimal support parameters of the side rock bolts and anchor cables were subsequently determined, and the support effect of gob-side entry in a mining scenario was verified. The results show that the support of the side rock bolts and anchor cables improves the mechanical properties and stress state of the anchorage body, producing a good protective effect on the coal body of the air-intake entry roof and side wall. This is beneficial to the stability of the side wall and the realization of the suspension effect for roof rock bolts and anchor cables, which in turn makes the surrounding rock maintenance of the gob-side entry to a thick coal seam more favorable.
\end{abstract}

Keywords Combined support $\cdot$ Split-level panel layout $\cdot$ External staggered gob-side entry $\cdot$ Adjacent roadways

\section{Introduction}

In recent years, the increasing demand for coal and the increased efficiency of coal production have led to a gradual shift from shallow to deep coal mining activities (Xie et al. 2015; Aghababaei et al. 2019; Ju et al. 2019). For deep mining, the roadway used for fully mechanized top coal caving faces the problem of controlling the surrounding rock to protect against rock burst, the influence of mining operations, and soft, thick coal roofs, which are prone to significant deformation and instability (Guo et al. 2019; Lu et al. 2019). In response to China's call to build resource-saving mines, gob-side entry driving technologies have been extensively used to avoid the waste of resources

Zhiqiang Wang

wzhiqianglhm@126.com

1 National University of Science and Technology MISIS, Moscow, Russia

2 School of Energy and Mining Engineering, China University of Mining and Technology-Beijing, Beijing 100083, China and secondary geological disasters caused by large coal pillars. (Zhang et al. 2019; Zuo et al. 2019).

Considerable research has investigated the control of the surrounding rock in the case of gob-side entry. Based on the characteristics of the surrounding rock, the stability principle of big and small structures was developed, providing a theoretical basis for the application of bolting (Hou and Li 2011). The width of the internal stress field and three fracture forms that occur in the overlying main roof were researched to determine the optimal position for gob-side entry ( $\mathrm{Li}$ et al. 2012; Wang et al. 2014).

Effectively controlling the deformation of the surrounding rock of the roadway and keeping it safe and unobstructed are the primary conditions for safe production within a mine. In terms of roadway support technology, rock bolts and anchor cables have become the main form of roadway support in coal mines. According to the support requirements of roadways under different geological conditions, the theory and technology have been further developed.

He and Guo (2014) and He et al. (2014 c) manufactured a type of anchor bolt that offers constant resistance and can 
undergo large deformations, while Kang et al. (2007, 2010a, b) developed a theoretical basis for high pretensioned stress and intensive supporting, and developed an associated bolting system that includes intensive bolts, steel strips, and cable bolts that offer enhanced mechanical functionality. Ma et al. (2013, 2015) manufactured long-extension bolts to ensure that the support system has sufficient length and extension, and He et al. (2015a, b), He and Zhang (2016) developed a multiplecable-girder-truss system, a key component of which is the composite structure of the steel beams, steel channels, and multiple cables anchored deep in the roof.

The common feature of existing research is that adjacent roadways on both sides of the coal pillar are driven along the floor of the coal seam, and the support scheme basically involves a single roadway. According to the three-dimensional spatial characteristics of the external staggered splitlevel panel layout (ESSPL), a suitable support scheme can be designed and the parameters of two adjacent roadways can be determined.

In this study, based on the combined support technology used in ESSPL, the geological conditions of Xinjulong Mine, Shandong Province, China, were taken as the research object to investigate the combined support mechanism of rock bolts and anchor cables. This paper focuses on the influence of the side rock bolt and anchor cable parameters on the mechanical properties of the anchorage body and the distribution characteristic of the support stress field, respectively, and verifies the support effect under the influence of mining.

\section{Combined support technology for adjacent roadways in ESSPL}

\subsection{ESSPL}

Since the split-level panel layout (SPL), or longwall mining with split-level gate roads (LMSG), was invented in 1998 (Zhao and Li 1998), it has been successfully applied in many production mines to control the mine pressure and improve the economic benefits.

As shown in Fig. 1, there are three types of roadway layout using split-level panels: the internal staggered layout, overlapping layout, and external staggered layout. The appropriate roadway layout is selected according to the actual engineering situation. The original intention of SPL was to enhance the recovery rate in conventional longwall top coal caving. Field applications of the internal staggered split-level panel layout (ISSPL) have been successful in Shanxi, Hebei, and Shandong Provinces (Zhao 2014; Wang et al. 2019). When the length of the end shields is not sufficient for internal staggered gob-side entry, the

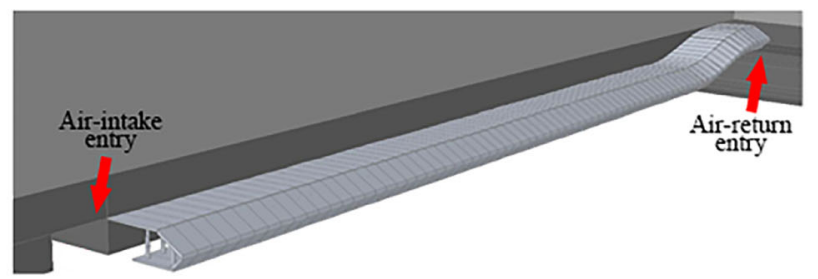

(a) 3-D view of the split-level panel

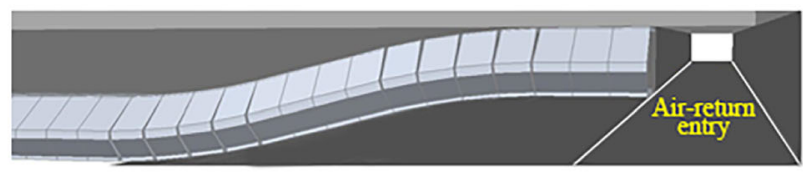

(b) Enlarged view of the split-level panel

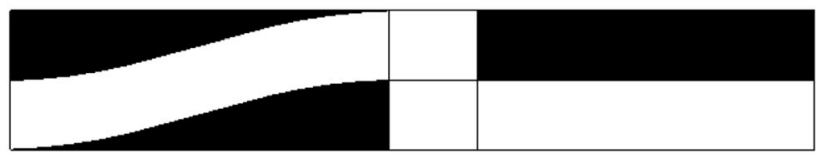

(c) Internal staggered layout

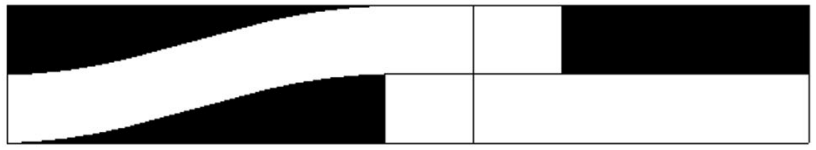

(d) Overlapping layout

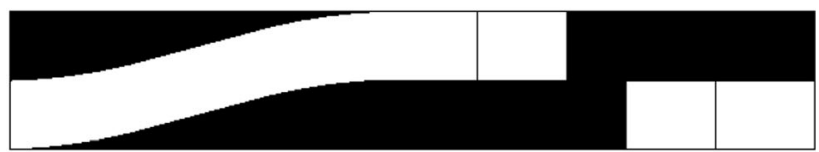

(e) External staggered layout

Fig. 1 Split-level panel layout

overlapping layout can be used. However, in this case, skip-mining is required for the successive panels, and the passive support of the gob-side entry greatly limits the advance rate. With ESSPL, the air-intake entry can be driven into areas with lower stress, so that a support system combining rock bolts and anchor cables can be adopted to ensure the continuation of mining. Recently, the theory underlying the ESSPL system has been improved (Wang 2016; Wang et al. 2020a, b). Enhanced technology has been used at Xiegou Mine, Fenyuan Mine, and other mines to realize active rock support.

Unlike the conventional longwall top coal caving and ISSPL, ESSPL has three-dimensional spatial characteristics, namely the horizontal staggered distance $L_{1}$ and the longitudinal staggered distance $L_{2}$ between two entries, as shown in Fig. 2. 


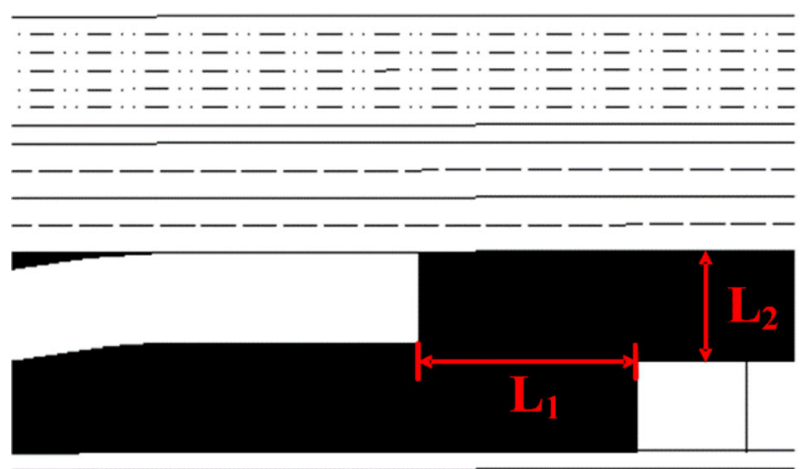

$-\div-\div-\div-\div-\div-\div-\div-\div$

Fig. 2 External staggered split-level panel layout

\subsection{Combined support technology for adjacent roadways}

According to the three-dimensional spatial characteristics of ESSPL, the design of a support scheme and the parameters of two adjacent roadways can be determined through the side support of the air-return entry driven along the coal seam roof. After the excavation of the seam, rock bolts and anchor cables are installed into the side coal wall, which can be reinforced by grouting. When the air-intake entry of successive panels is driven along the coal seam floor, the rock bolts and anchor cables can be installed on the roof to realize the combined support of adjacent roadways.

The characteristics of the combined support technology shown in Fig. 3 are as follows:

(1) The air-return entry is driven along the coal seam roof. Roof rock bolts and anchor cables are directly installed into the immediate roof and the main roof, giving full play to the suspension effect of rock bolts and anchor cables;

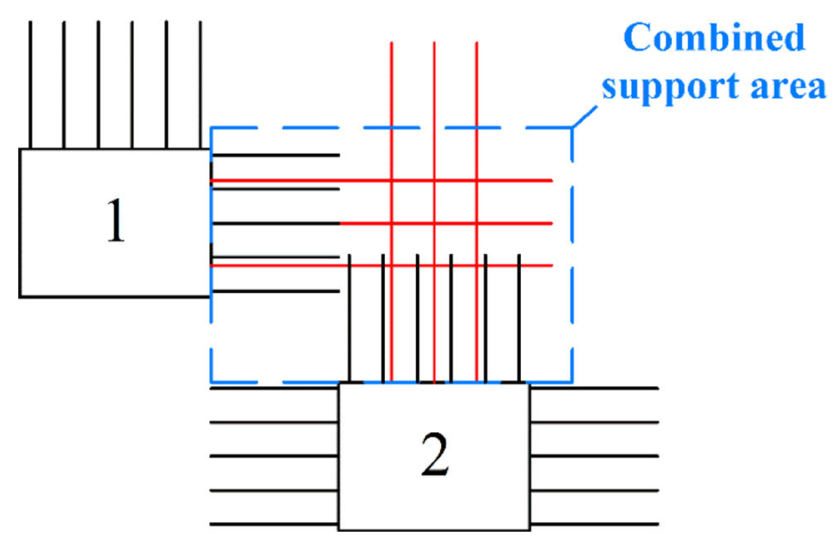

Fig. 3 Combined support technology for adjacent roadways. Note: 1 refers to air-return entry of the active panel, 2 refers to air-intake entry of the successive panel
(2) A combined anchorage area is formed between the adjacent roadways, enhancing the cohesion $c$, internal friction angle $\varphi$, compressive strength $\sigma$, and shear strength $\tau$ of the anchorage body;

(3) The combined anchorage area provides a strong anchoring force for the roof rock bolts and anchor cables of the air-intake entry, thus producing a stronger suspension effect.

Overall, using ESSPL and combined support technology gives full play to the suspension effect of roadway support under various geological and mining conditions, and expands the application scope of suspension theory with simple and economic characteristics.

\section{Engineering case}

Xinjulong Mine is located in Heze City, Shandong Province, China. In the second mining area, \#No.3 coal seam is mined at a depth of around $800 \mathrm{~m}$. The thickness of the coal seam varies from 3.8 to $8.5 \mathrm{~m}$, and the average thickness is $7.2 \mathrm{~m}$. The inclination angle of the coal seam varies from $6.0^{\circ}$ to $9.6^{\circ}$ with an average inclination of $7.8^{\circ}$. The Protodyakonov coefficient of the coal is 1.59 and its density is $1360 \mathrm{~kg} / \mathrm{m}^{3}$. The coal seam has a stable occurrence and a complex structure, with mudstone or carbonaceous mudstone of thickness $0.1-0.35 \mathrm{~m}$ in the middle. The coal quality is mainly fat coal with $1 / 3$ coking coal.

The active $2301 \mathrm{~S}$ panel, which is adopted in fully mechanized top-caving technology, measures $2319 \mathrm{~m}$ in length along the strike and is $274 \mathrm{~m}$ wide along the dip. A $20-\mathrm{m}$ coal pillar is positioned between the $2301 \mathrm{~S}$ panel and $2302 \mathrm{~S}$ panel. Rectangular roadways measuring $4.5 \mathrm{~m} \times 3.5 \mathrm{~m}$ are driven along the coal seam floor. The supporting parameters are as follows:

(1) Six rock bolts and two anchor cables are used to support the roof of the entry. The high-strength lefthanded longitudinal reinforcement threaded steel bolts measure $\Phi 22 \mathrm{~mm} \times 2500 \mathrm{~mm}$, with a spacing and row spacing of $850 \mathrm{~mm} \times 800 \mathrm{~mm}$. The anchor cables measure $\Phi 18.9 \mathrm{~mm} \times 6300 \mathrm{~mm}$, with a spacing and row spacing of $2400 \mathrm{~mm} \times 800 \mathrm{~mm}$.

(2) Five rock bolts and two anchor cables are used to support the coal side of the entry. The same model of steel bolts is used, with a spacing and row spacing of $750 \mathrm{~mm} \times 800 \mathrm{~mm}$. The anchor cables measure $\Phi 18.9 \mathrm{~mm} \times 4300 \mathrm{~mm}$, with a spacing and row spacing of $2400 \mathrm{~mm} \times 800 \mathrm{~mm}$. 


\section{Influence of rock bolt parameters on mechanical properties of anchorage body}

This section describes the use of FLAC ${ }^{3 \mathrm{D}}$ to analyze the influence of the rock bolt parameters on the mechanical properties of the anchorage body. For this, the control variable method is adopted. The related parameters of the rock bolts include the spacing, pre-tightening force, length, and diameter, as listed in Table 1.

The numerical simulations were based on the original mechanical parameters of No. 3 coal seam in the second mining area of Xinjulong Mine, as listed in Table 2. The FLAC $^{3 \mathrm{D}}$ software was used to perform modeling and calculations using the Mohr-Coulomb failure criterion. The model domain extended over $3.5 \mathrm{~m}$ (length) $\times 3.0 \mathrm{~m}$ (width) $\times 3.5 \mathrm{~m}$ (height) and was divided into 36,750 cells and 40,176 nodes, as shown in Fig. 4.

During compression tests, the compression speed of the compression member affects the final stress-strain results. Thus, to fit the original parameters, numerical simulations of the specimen were repeated numerous times with different loading speeds. In the numerical simulations, the test specimen was subjected to three mechanical tests of uniaxial compression, a 1-MPa confining pressure, and a 2-MPa confining pressure, as shown in Fig. 5a. The corresponding Mohr-Coulomb stress circle is shown in Fig. 5b. The original elastic modulus of the experimental body was $26.2 \mathrm{GPa}$, the uniaxial compressive strength was $10.35 \mathrm{MPa}$, the cohesion was $3.08 \mathrm{MPa}$, and the internal friction angle was $28.46^{\circ}$.

\subsection{Influence of rock bolt spacing on mechanical properties of anchorage body}

To examine the effect of the rock bolt spacing, the rock bolt pre-tightening force was set to $40 \mathrm{kN}$ and the rock bolt diameter and length were set to $16 \mathrm{~mm}$ and $2.2 \mathrm{~m}$, respectively.

Repeat tests were conducted for each model. First, the uniaxial compressive strength was tested, and then the compressive strength experiment was conducted under both 1- and 2- MPa confining pressures to find the cohesion and internal friction angle. The shear strength of the

Table 1 Experimental parameters of rock bolts

\begin{tabular}{llllll}
\hline Parameter & Value & & & \\
\hline Spacing $(\mathrm{m})$ & 0.6 & 0.8 & 1.0 & 1.2 & 1.4 \\
Pre-tightening force $(\mathrm{kN})$ & 40 & 60 & 80 & 100 & 120 \\
Length $(\mathrm{m})$ & 2.2 & 2.4 & 2.6 & 2.8 & 3.0 \\
Diameter $(\mathrm{mm})$ & 16 & 18 & 20 & 22 & 24 \\
\hline
\end{tabular}

anchorage body was calculated from the above data. The experimental results were combined to clarify the influence of the rock bolt spacing on the uniaxial compressive strength, shear strength, cohesion, and internal friction angle of the anchorage body, as shown in Fig. 6.

As shown in Fig. 6a, the uniaxial compressive strength and shear strength of the anchorage body exhibit an increasing trend as the density of the rock bolts increases. The uniaxial compressive strength with a spacing of $0.6 \mathrm{~m}$ is $0.43 \mathrm{MPa}$ higher than that with a spacing of $1.4 \mathrm{~m}$, and $0.54 \mathrm{MPa}$ higher than the original rock parameter. The shear strength of the $0.6-\mathrm{m}$ spacing is $0.65 \mathrm{MPa}$ higher than that of the 1.4-m spacing, and $0.82 \mathrm{MPa}$ above the original rock parameter.

As shown in Fig. 6b, a decrease in the rock bolt spacing increases both the cohesion and internal friction angle of the anchorage body. The increase in cohesion is not obvious, with a rise of only $0.04 \mathrm{MPa}$ as the spacing decreases from 1.4 to $0.6 \mathrm{~m}$. The internal friction angle for the $0.6-\mathrm{m}$ spacing is $1.4^{\circ}$ higher than that for the $1.4-\mathrm{m}$ spacing and $1.83^{\circ}$ higher than the original rock parameter.

In summary, the uniaxial compressive strength $\sigma$, internal friction angle $\varphi$, cohesion $c$, and shear strength $\tau$ all improve with increasing support density, but the rate of increase decreases once the bolt spacing is less than $0.8 \mathrm{~m}$. Each mechanical parameter improved the most as the spacing decreased from 1.2 to $0.8 \mathrm{~m}$. Thus, subsequent simulations used a rock bolt spacing of $0.8 \mathrm{~m}$.

\subsection{Influence of rock bolt pre-tightening force on mechanical properties of anchorage body}

Next, rock bolt pre-tightening forces of 40,60, 80, 100 and $120 \mathrm{kN}$ were examined. The rock bolt spacing was set to $0.8 \mathrm{~m}$, and the diameter and length were fixed to $16 \mathrm{~mm}$ and $2.2 \mathrm{~m}$, respectively. The experimental results are shown in Fig. 7.

As shown in Fig. 7a, the uniaxial compressive strength and shear strength of the anchorage body exhibit an increasing trend as the rock bolt pre-tightening force increases. As the rock bolt pre-tightening force increases from 40 to $120 \mathrm{kN}$, the uniaxial compressive strength increases by $0.49 \mathrm{MPa}$, giving an increase of $0.98 \mathrm{MPa}$ compared with the original rock parameter. The shear strength in the $120 \mathrm{kN}$ case is $0.6 \mathrm{MPa}$ higher than that in the $40 \mathrm{kN}$ case, and $1.36 \mathrm{MPa}$ higher than the original rock parameter.

As shown in Fig. 7b, the cohesion and internal friction angle of the anchorage body also increase as the rock bolt pre-tightening force increases. For a rock bolt pre-tightening force of $120 \mathrm{kN}$, the cohesion is $0.09 \mathrm{MPa}$ higher than with a force of $40 \mathrm{kN}$, and $0.131 \mathrm{MPa}$ higher than the original rock parameter. The rock bolt pre-tightening force 
Table 2 Rock mechanics parameters of No. 3 coal seam in Xinjulong Mine

\begin{tabular}{llllll}
\hline $\begin{array}{l}\text { Uniaxial compressive strength } \\
(\mathrm{MPa})\end{array}$ & $\begin{array}{l}\text { Uniaxial tensile strength } \\
(\mathrm{MPa})\end{array}$ & $\begin{array}{l}\text { Elastic modulus } \\
(\mathrm{GPa})\end{array}$ & $\begin{array}{l}\text { Poisson's } \\
\text { ratio }\end{array}$ & $\begin{array}{l}\text { Cohesion } \\
(\mathrm{MPa})\end{array}$ & $\begin{array}{l}\text { Internal friction angle } \\
\left({ }^{\circ}\right)\end{array}$ \\
\hline 10.40 & 0.51 & 26.28 & 0.29 & 3.1 & 28.5 \\
\hline
\end{tabular}

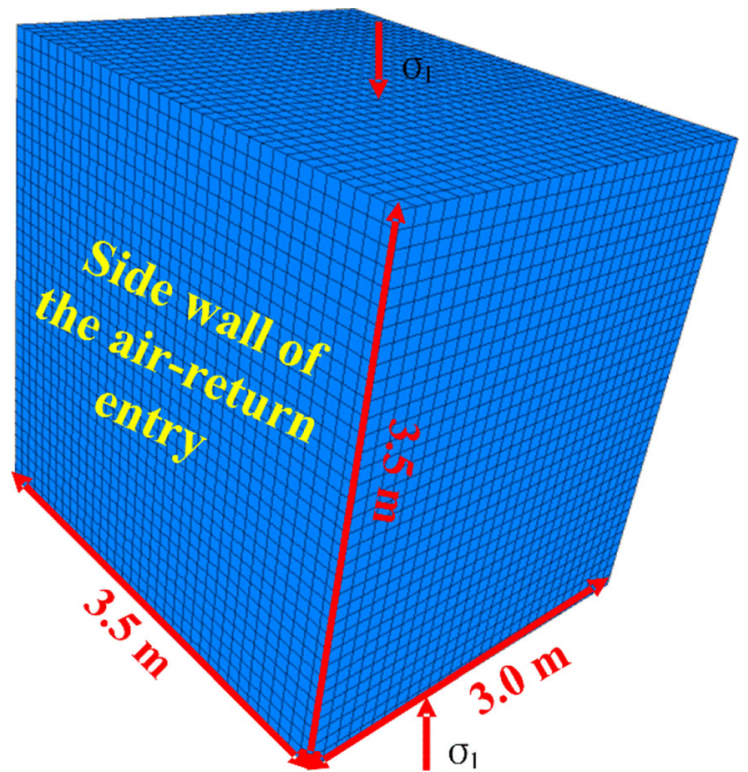

Fig. 4 FLAC $^{3 \mathrm{D}}$ model of anchorage body

has a significant effect on the internal friction angle. With a pre-tightening force of $120 \mathrm{kN}$, the internal friction angle is $0.82^{\circ}$ higher than that of the $40 \mathrm{kN}$ case, representing an increase of $2.47^{\circ}$ from the original rock parameter.

According to the comprehensive analysis of Fig. 7, an increase in the rock bolt pre-tightening force serves to enhance the uniaxial compressive strength $\sigma$, internal friction angle $\varphi$, cohesion $c$, and shear strength $\tau$. Considering that the rate of increase rapidly dropped off once the pre-tightening force reached $80 \mathrm{kN}$, subsequent simulations used a rock bolt pre-tightening force of $80 \mathrm{kN}$.

\subsection{Influence of rock bolt diameter on mechanical properties of anchorage body}

According to Table 1, rock bolt diameters of 16, 18, 20, 22 and $24 \mathrm{~mm}$ were investigated. The rock bolt spacing was set to $0.8 \mathrm{~m}$, the pre-tightening force was $80 \mathrm{kN}$, and the bolt length was $2.2 \mathrm{~m}$. The experimental results are shown in Fig. 8 .

As shown in Fig. 8a, the uniaxial compressive strength and shear strength of the anchorage body increase as the rock bolt diameter increases. When the anchor diameter reaches $24 \mathrm{~mm}$, the uniaxial compressive strength is $0.27 \mathrm{MPa}$ greater than that with a $16-\mathrm{mm}$ bolt, an increase

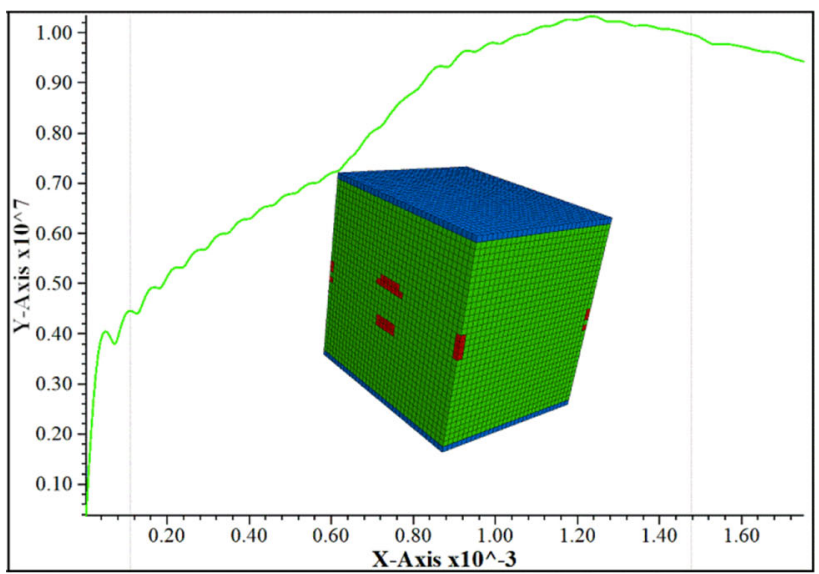

(a) Numerical compression test

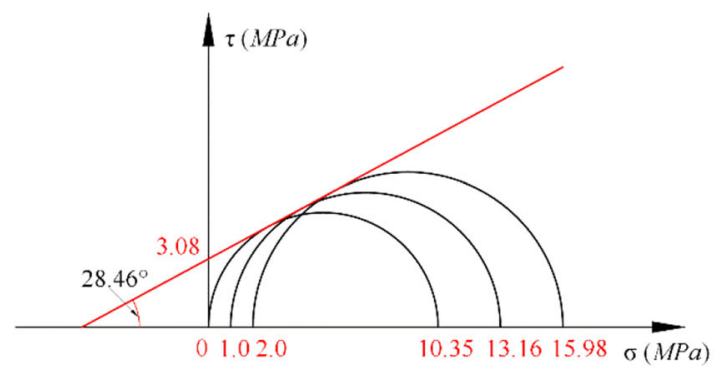

(b) Mohr-Coulomb stress circle

Fig. 5 Compression test to fit original parameters

of 1.1 MPa over the original rock parameter. The shear strength increases by $0.4 \mathrm{MPa}$ as the rock bolt diameter increases from 16 to $24 \mathrm{~mm}$, representing an increase of 1.54 MPa compared with the original rock.

As shown in Fig. 8b, the cohesion and internal friction angle of the anchorage body also increase as the rock bolt diameter increases. When the rock bolt diameter is $24 \mathrm{~mm}$, the cohesion is $0.026 \mathrm{MPa}$ greater than with a $16-\mathrm{mm}$ bolt, and $0.13 \mathrm{MPa}$ greater than the original rock parameter. The internal friction angle increases by $0.78^{\circ}$ as the diameter increases from 16 to $24 \mathrm{~mm}$, representing an increase of $2.96^{\circ}$ over the original case.

Comprehensive analysis shows that when the rock bolt diameter reaches $22 \mathrm{~mm}$, the increment in the mechanical properties is significant, but the rate of increase slows down when the rock bolt diameter exceeds $22 \mathrm{~mm}$. Therefore, 


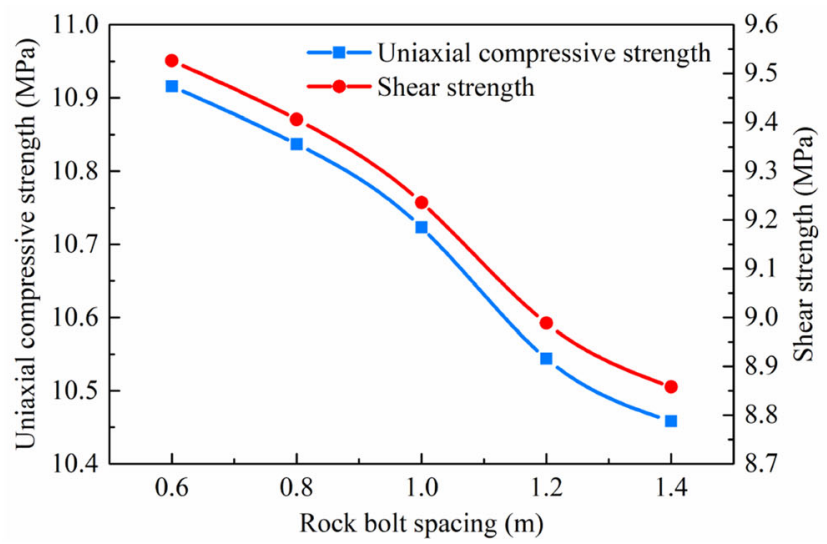

(a) Influence of rock bolt spacing on uniaxial compressive strength and shear strength

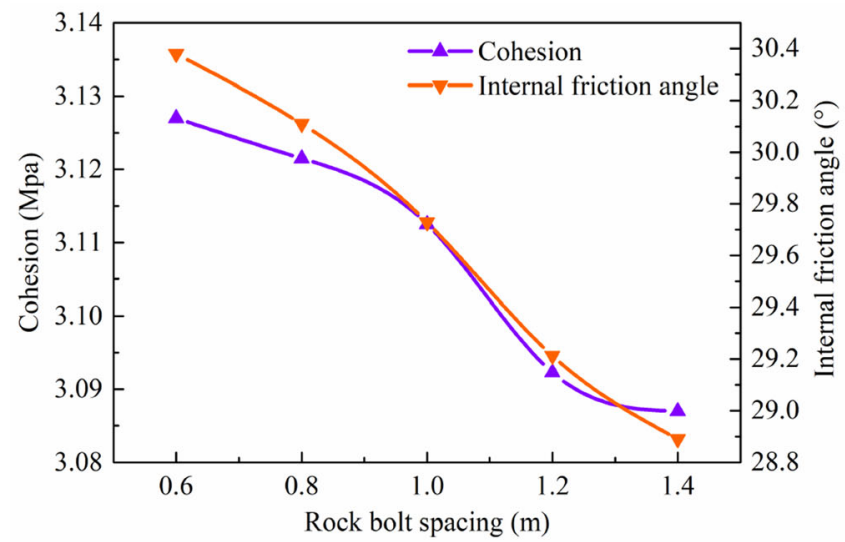

(b) Influence of rock bolt spacing on cohesion and internal friction angle

Fig. 6 Influence of rock bolt spacing on mechanical properties of anchorage body

the rock bolt diameter was set to $22 \mathrm{~mm}$ in subsequent simulations.

\subsection{Influence of rock bolt length on mechanical properties of anchorage body}

According to Table 1, rock bolts with lengths of 2.2, 2.4, 2.6, 2.8 and $3.0 \mathrm{~m}$ were examined. The rock bolt spacing was set to $0.8 \mathrm{~m}$, the pre-tightening force was $80 \mathrm{kN}$, and the bolt diameter was $22 \mathrm{~mm}$. The experimental results are shown in Fig. 9.

As shown in Fig. 9a, as the rock bolt length increases from 2.2 to $3.0 \mathrm{~m}$, the uniaxial compressive strength and shear strength of the anchorage body exhibit an increasing trend. The uniaxial compression strength with the $3.0-\mathrm{m}$ rock bolt length has increased by $0.34 \mathrm{MPa}$ compared with that using a 2.2-m bolt, representing an increase of $1.42 \mathrm{MPa}$ over the original rock parameter. The shear strength increases by $0.49 \mathrm{MPa}$ as the length increases from 2.2 to $3.0-\mathrm{m}$ and is eventually $1.98 \mathrm{MPa}$ higher than the original rock parameter.

As shown in Fig. 9b, an increase in the rock bolt length increases both the cohesion and internal friction angle of the anchorage body. When the rock bolt length is $3.0 \mathrm{~m}$, the cohesion and internal friction angle are $0.048 \mathrm{MPa}$ and $0.86^{\circ}$ higher, respectively, than when the length is $2.2-\mathrm{m}$, representing increases of $0.168 \mathrm{MPa}$ and $3.77^{\circ}$ over the original rock parameters.

Analysis of Fig. 9 indicates that the rock bolt length is positively related to all parameters, although an inflection point appears at a length of $2.4 \mathrm{~m}$. When the rock bolt length reaches $2.4 \mathrm{~m}$, the growth rate of all mechanical parameters starts to increase rapidly. Thus, the rock bolt length was set to $3.0 \mathrm{~m}$ in subsequent simulations. 


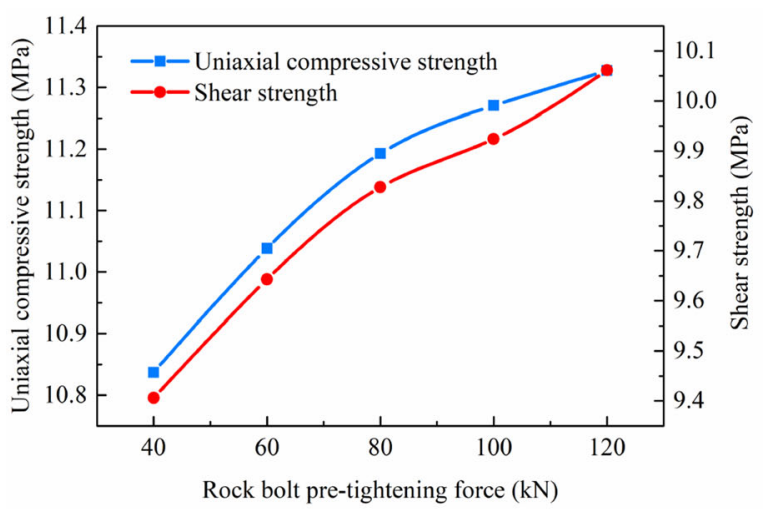

(a) Influence of rock bolt pre-tightening force on uniaxial compressive strength and shear strength

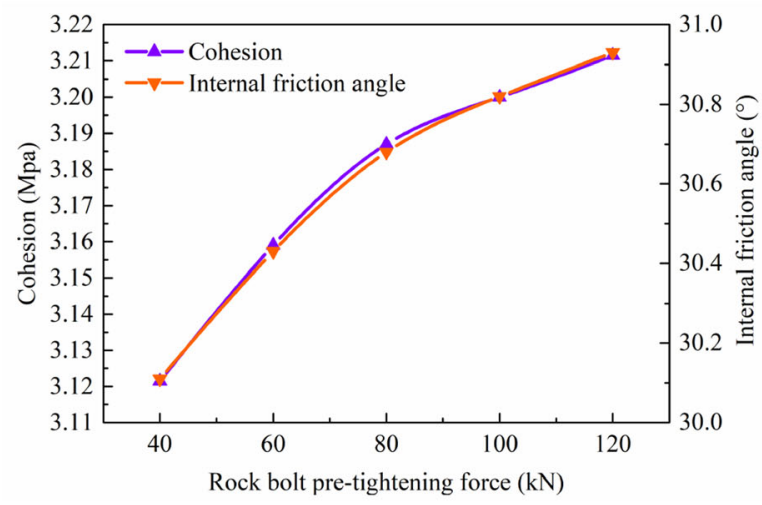

(b) Influence of rock bolt pre-tightening force on cohesion and internal friction angle

Fig. 7 Influence of rock bolt pre-tightening force on mechanical properties of anchorage body

\subsection{Optimal support parameters of side rock bolts for air-return entry}

The above sections identified the influence of the rock bolt spacing, pre-tightening force, bolt diameter, and bolt length on the mechanical parameters of the anchorage body. Reasonable values of the rock bolt support parameters were determined to be $0.8 \mathrm{~m}$ for the rock bolt spacing, $80 \mathrm{kN}$ for the rock bolt pre-tightening force, $22 \mathrm{~mm}$ for the rock bolt diameter, and $3.0 \mathrm{~m}$ for the rock bolt length. The mechanical properties of the anchorage body in this support scheme are $11.78 \mathrm{MPa}$ for the uniaxial compressive strength, 10.67 MPa for the shear strength, 3.24 MPa for the cohesion, and $32.2^{\circ}$ for the internal friction angle. These values represent improvements of $1.42,1.98$, $0.168 \mathrm{MPa}$, and $3.77^{\circ}$, respectively, over the original rock parameters.

By comparing the variations in the mechanical properties caused by changes in the rock bolt parameters, combined with actual engineering experience, it is clear that the rock bolt pre-tightening force and spacing have a significant influence on the mechanical properties of the anchorage body, whereas the length and diameter of the rock bolt have little effect. Therefore, in terms of actual production, the design of a rock bolt support scheme should focus on the rock bolt spacing and pre-tightening force.

\section{Influence of anchor cable parameters on the support stress distribution of lateral coal body}

The action mechanism of rock bolts and anchor cables can be divided into two components: the influence on the mechanical parameters of the anchorage body, and the effect on the stress state of the surrounding rock, whereby the stress state develops in a direction conducive to stability. During underground mining, the original rock stress field, mining stress field, and support stress field interact with each other. The original rock stress field and mining stress field are much larger than the support stress field formed by the support structure, which is not conducive to 


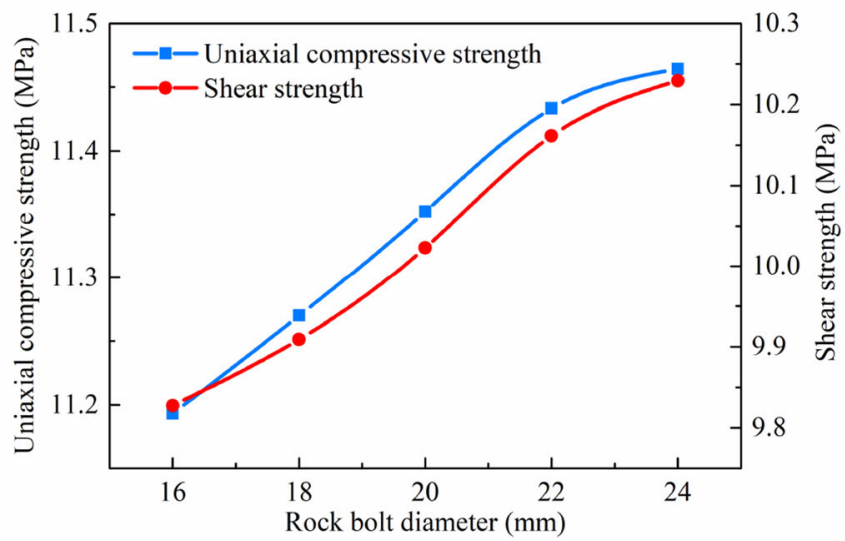

(a) Influence of rock bolt diameter on uniaxial compressive strength and shear strength

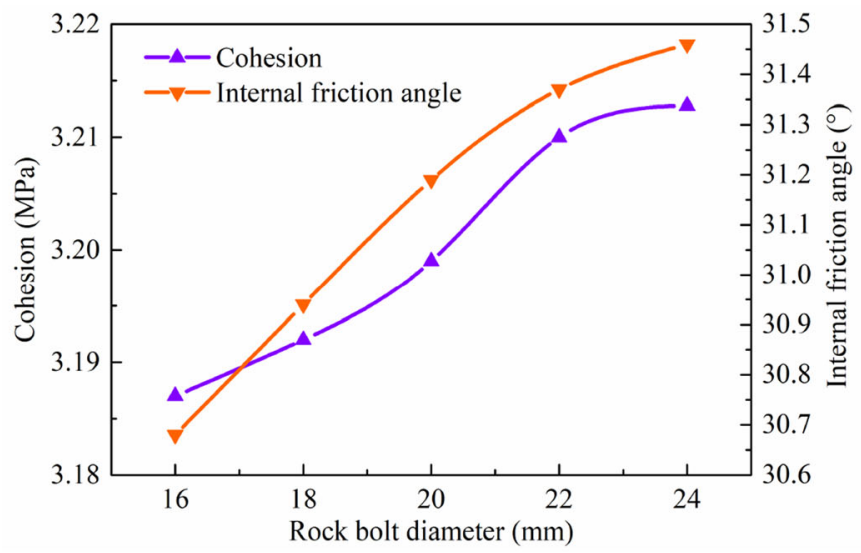

(b) Influence of rock bolt diameter on cohesion and internal friction angle

Fig. 8 Influence of rock bolt diameter on mechanical properties of anchorage body

observing the support stress field (Wang et al. 2008). By neglecting the original rock stress field and using the optimal rock bolt scheme, FLAC ${ }^{3 \mathrm{D}}$ was used to analyze changes in the distribution of the support stress field caused by the different anchor cable parameters, thus providing a basis for the reasonable design of the support parameters. The main parameters related to the anchor cables are their length, spacing, and pre-tightening force, as listed in Table 3.

The model domain was set to cover $50 \mathrm{~m}$ (length) $\times$ $20 \mathrm{~m}$ (width) $\times 50 \mathrm{~m}$ (height), and the air-return entry size was set to $4.5 \mathrm{~m}$ (width) $\times 3.5 \mathrm{~m}$ (height). The computational mesh contained a total of 295,000 elements and 314,874 nodes, as shown in Fig. 10. The rock bolts and anchor cables were installed at staggered intervals along the strike, as shown in Fig. 11.

The simulations were performed according to the MohrCoulomb failure criterion. The horizontal and vertical velocities of the upper and bottom boundaries were constrained, as was the horizontal velocity of the side boundaries. Five rock strata with different properties were established in the model, with the rock parameters set to recreate the conditions at Xinjulong Mine; the five strata are described in Table 4.

\subsection{Influence of anchor cable length on the support stress distribution of lateral coal body}

First, anchor cable lengths of $6.0,8.0,10.0$, and $12.0 \mathrm{~m}$ were investigated. For the remaining variables, the pretightening force was set to $150 \mathrm{kN}$ and the spacing was set to $1.4 \mathrm{~m}$. The experimental results are shown in Fig. 12 .

From Fig. 12a, the right side of the air-return entry is successively a rock bolt-anchor cable support compressive stress zone, an anchor cable support compressive stress zone, and an anchor cable support tension stress zone. In the rock bolt-anchor cable support compressive stress zone, the combined support effect of side rock bolts and anchor cables forms a compressive stress zone of approx. 0.25 MPa. In the anchor cable compressive stress zone, a 


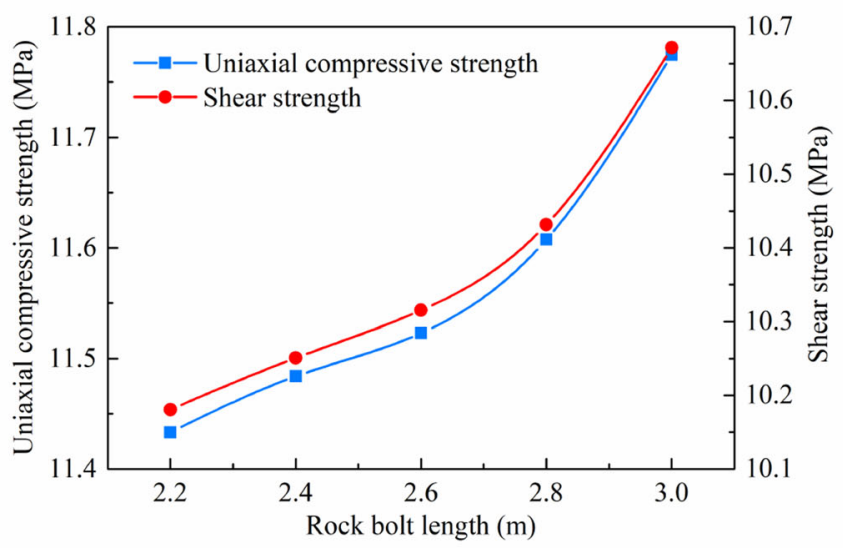

(a) Influence of rock bolt length on uniaxial compressive strength and shear strength

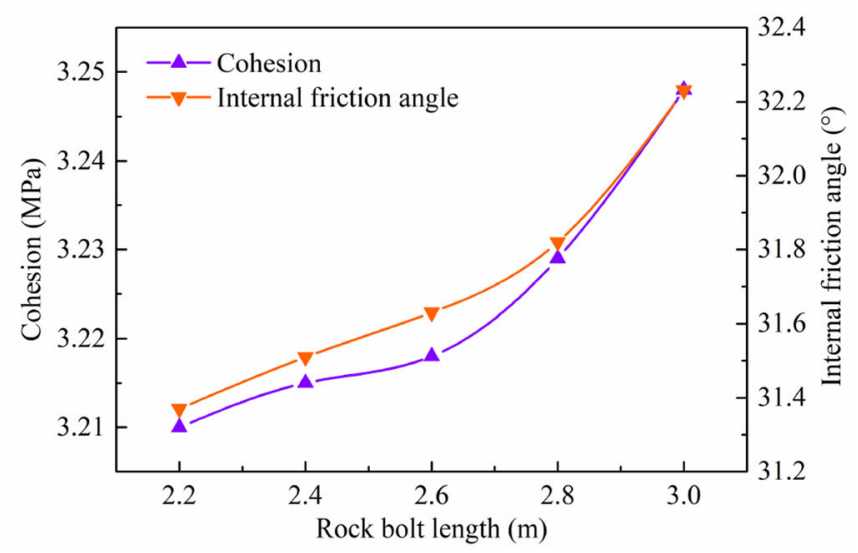

(b) Influence of rock bolt length on cohesion and internal friction angle

Fig. 9 Influence of rock bolt length on mechanical properties of anchorage body

Table 3 Experimental parameters of anchor cables

\begin{tabular}{lllll}
\hline Parameter & Value & & \\
\hline Length $(\mathrm{m})$ & 6.0 & 8.0 & 10.0 & 12.0 \\
Spacing $(\mathrm{m})$ & 1.4 & 1.2 & 1.0 & 0.8 \\
Pre-tightening force $(\mathrm{kN})$ & 150 & 200 & 250 & 300 \\
\hline
\end{tabular}

magnitude of approx. $0.15 \mathrm{MPa}$ forms under the support effect of the anchor cable. A stress concentration zone appears at the initial stage of the cable anchoring, and the tensile stress is approx. 0.07 $\mathrm{MPa}$.

Through a comparative analysis of Fig. 12, it can be found that, as the side anchor cable becomes longer, its influence range gradually increases. However, as the side anchor cable length increases, the stress in the compressive stress zone of the anchor cable support gradually decreases. When the anchor cable reaches $10 \mathrm{~m}$, the stress value in the

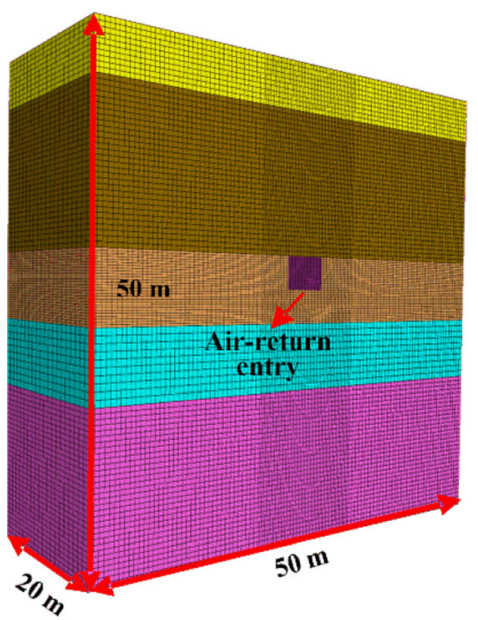

Fig. 10 FLAC $^{3 D}$ model used to investigate the anchor cable parameters

compressive stress zone of the anchor cable is only approx. $0.08 \mathrm{MPa}$. 


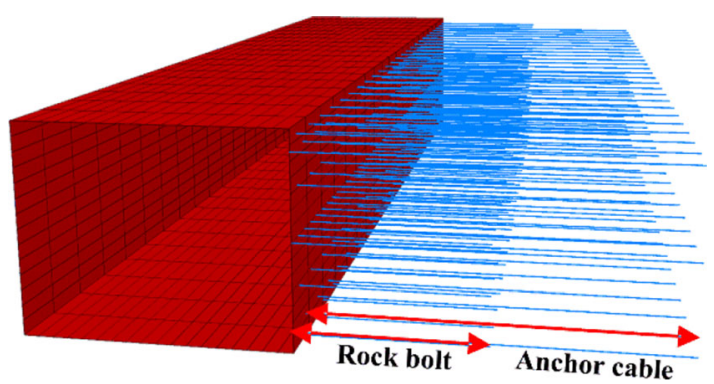

Fig. 11 Side support structure of air-return entry

Numerical simulations show that increasing the length of the anchor cable can significantly increase the support range. However, under the same pre-tightening force, increasing the length of the anchor cable tends to weaken the prestressing effect of the side anchor cable. Therefore, the pre-tightening force of the side anchor cable should be increased as the length of the anchor cable increases. According to this analysis, the length of the side anchor cable should be neither too short nor too long. The optimal length is related to the air-intake entry position of the successive panel, so as to fully control the roof coal of the air-return entry. In this study, the horizontal staggered distance is set to $3.0 \mathrm{~m}$ and the roadway width is $4.5 \mathrm{~m}$. Thus, an anchor cable length of $8.0 \mathrm{~m}$ was used in the following simulations.

\subsection{Influence of anchor cable spacing on the support stress distribution of lateral coal body}

Anchor cable spacings of $1.4,1.2,1.0$ and $0.8 \mathrm{~m}$ were examined. To ensure the staggered installation of anchor cables and rock bolts, the row spacing of the anchor cables was set to $1.6 \mathrm{~m}$. The length of the anchor cable was set to $8.0 \mathrm{~m}$ and the pre-tightening force was $150 \mathrm{kN}$. The horizontal support stress fields for the different spacings are shown in Fig. 13.

As the anchor cable spacing increases, the stress in the support stress field gradually increases. When the spacing between the anchor cables is $1.4 \mathrm{~m}$, the stress value in the rock bolt-anchor cable support compressive stress zone is $0.175 \mathrm{MPa}$ and that in the anchor cable support compressive stress zone is $0.075 \mathrm{MPa}$. When the spacing between the anchor cables is $0.8 \mathrm{~m}$, the stress values are $0.28 \mathrm{MPa}$ and $0.175 \mathrm{MPa}$, respectively, which proves that reducing the spacing between anchor cables is beneficial to improving the control effect of the anchor cables on the lateral coal body.

When the spacing distance is $1.0 \mathrm{~m}$, high stress ranges interconnect in the anchor cable compressive stress zone, and the support stress fields formed by the rock bolts and anchor cables become superimposed on one another. The control effect on the lateral coal body is then more obvious. Therefore, subsequent simulations used an anchor cable spacing of $1.0 \mathrm{~m}$.

\subsection{Influence of anchor cable pre-tightening force on the support stress distribution of lateral coal body}

The pre-tightening force of the anchor cable was successively set to $150,200,250$ and $300 \mathrm{kN}$. The length of the anchor cable was set to $8.0 \mathrm{~m}$ and the spacing between the anchor cables was $1.0 \mathrm{~m}$. The test results are shown in Fig. 14.

Figure 14a shows that a small pre-tightening force results in a support compressive stress field of only approx. 0.15 MPa forming at the tail and beginning of the anchor cable. Through a comparative analysis of Fig. 14a$\mathrm{d}$, it can be found that, under the control of other variables, an increase in the pre-tensioning force of the side anchor cables gradually increases the range of the support pressure stress area. When a pre-tightening force of $250 \mathrm{kN}$ is applied, high stress ranges interconnect in the anchor cable compressive stress zone, and the stress value reaches approx. 0.245 $\mathrm{MPa}$. The stress value and range of the rock bolt-anchor cable support compressive stress zone are large, giving full play to the combined support effect.

Table 4 Properties of rock strata for numerical modeling

\begin{tabular}{lccllll}
\hline Lithology & $\begin{array}{l}\text { Bulk modulus } \\
(\mathrm{GPa})\end{array}$ & $\begin{array}{l}\text { Shear modulus } \\
(\mathrm{GPa})\end{array}$ & $\begin{array}{l}\text { Density }(\mathrm{kg} / \\
\left.\mathrm{m}^{3}\right)\end{array}$ & $\begin{array}{l}\text { Internal friction angle } \\
\left({ }^{\circ}\right)\end{array}$ & $\begin{array}{l}\text { Cohesion } \\
(\mathrm{MPa})\end{array}$ & $\begin{array}{l}\text { Tensile strength } \\
(\mathrm{GPa})\end{array}$ \\
\hline Fine sandstone & 15.80 & 11.30 & 2700 & 42.0 & 5.50 & 2.40 \\
Siltstone & 8.40 & 5.90 & 2350 & 39.0 & 4.20 & 1.20 \\
No.3 Coal & 11.90 & 7.10 & 1400 & 28.5 & 3.10 & 0.51 \\
$\quad$ seam & & & & 39.0 & 4.20 & 1.20 \\
Siltstone & 8.40 & 5.90 & 2350 & 42.0 & 5.50 & 2.40 \\
Fine sandstone & 15.80 & 11.30 & 2700 & & &
\end{tabular}




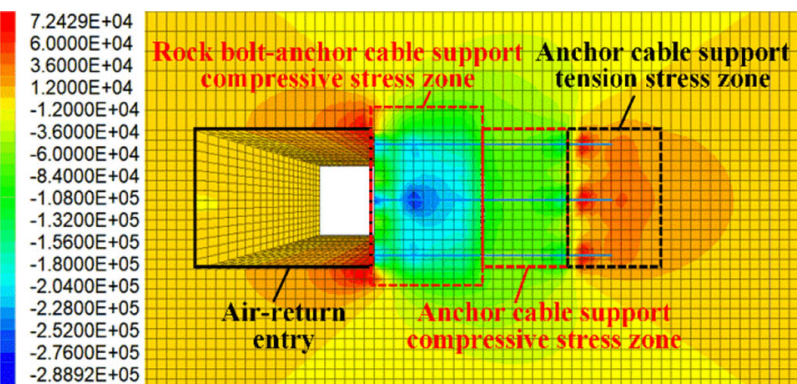

(a) Anchor cable length of $6.0 \mathrm{~m}$

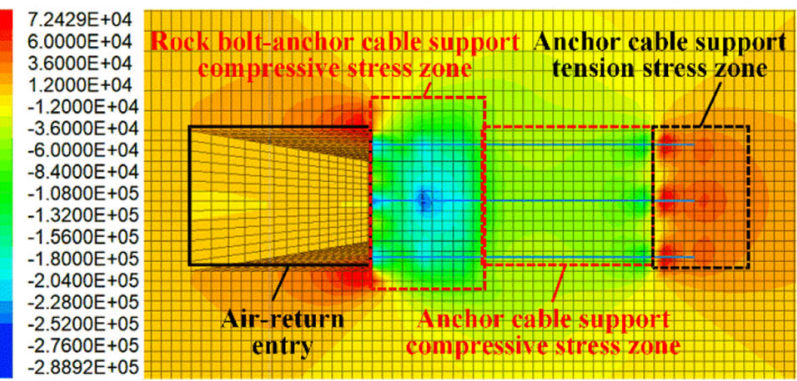

(b) Anchor cable length of $8.0 \mathrm{~m}$

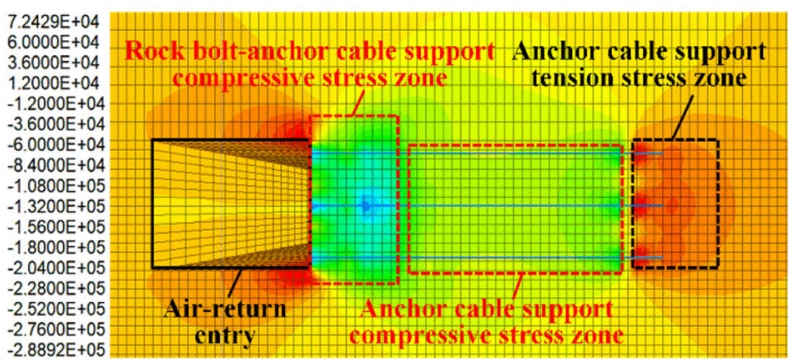

(c) Anchor cable length of $10.0 \mathrm{~m}$

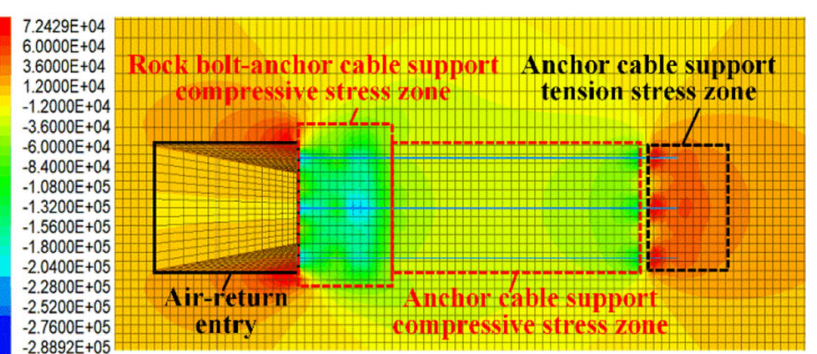

(d) Anchor cable length of $12.0 \mathrm{~m}$

Fig. 12 Horizontal support stress fields with different anchor cable lengths

\subsection{Optimal support parameters of side anchor cable for air-return entry}

Optimization of the anchor cable support parameters suggests a length of $8.0 \mathrm{~m}$, spacing of $1.0 \mathrm{~m}$, and pre-tightening force of $250 \mathrm{kN}$. Under this support scheme, the

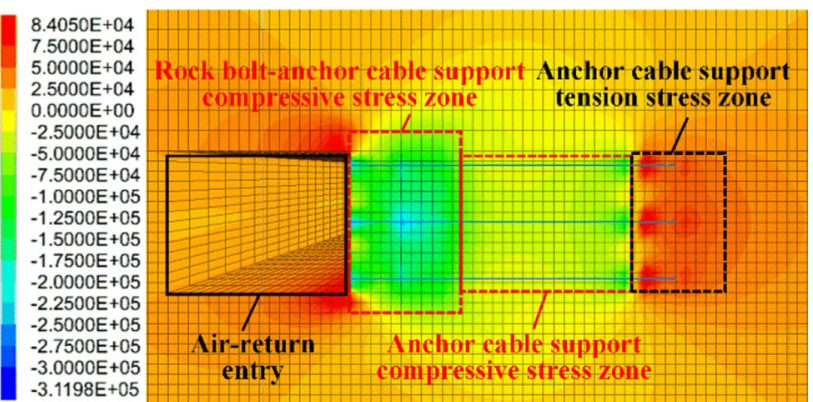

(a) Anchor cable spacing of $1.4 \mathrm{~m}$

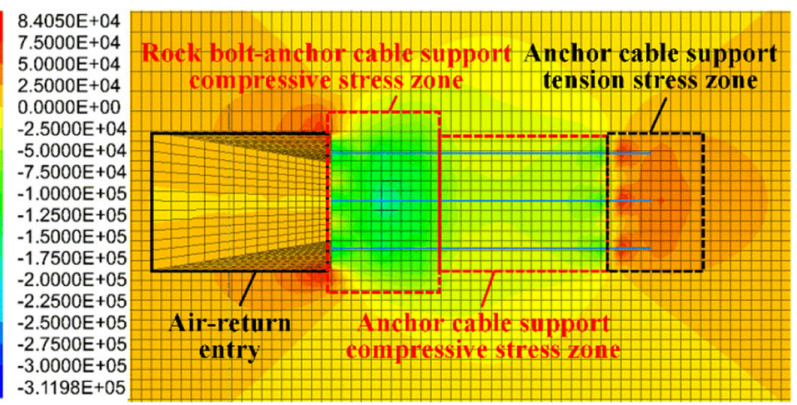

(b) Anchor cable spacing of $1.2 \mathrm{~m}$

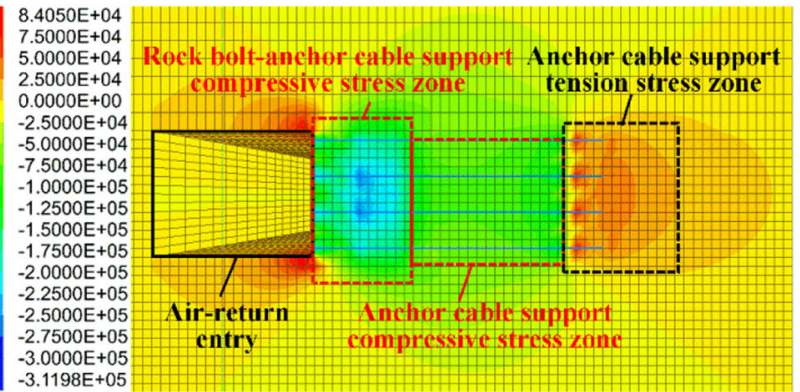

(c) Anchor cable spacing of $1.0 \mathrm{~m}$

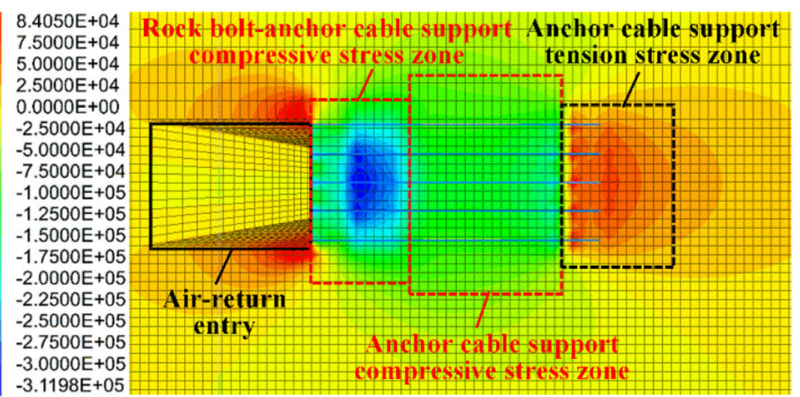

(d) Anchor cable spacing of $0.8 \mathrm{~m}$

Fig. 13 Horizontal support stress fields with different anchor cable spacings

superposition effect between rock bolts and anchor cables is obvious. A support compressive stress field of approx. 0.3 $\mathrm{MPa}$ forms in the rock bolt-anchor cable 


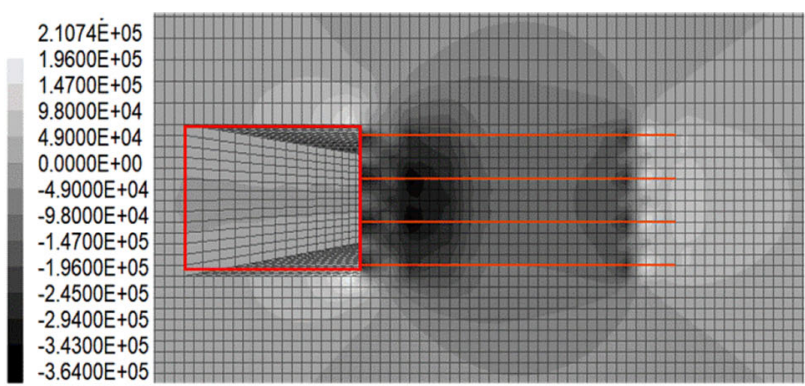

(a) Anchor cable pre-tightening of $150 \mathrm{kN}$

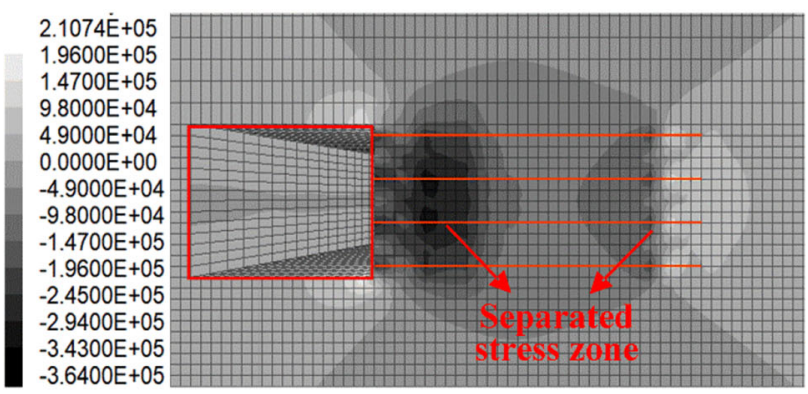

(b) Anchor cable pre-tightening of $200 \mathrm{kN}$

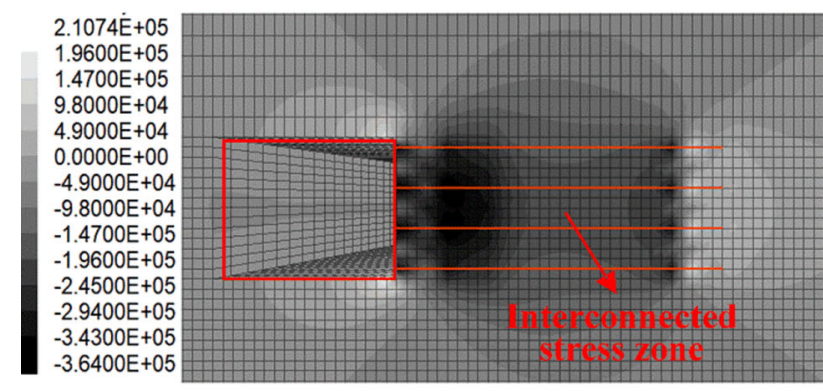

(c) Anchor cable pre-tightening of $250 \mathrm{kN}$

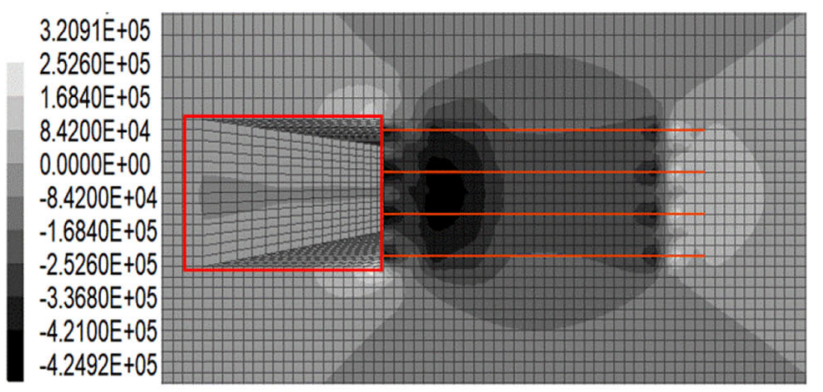

(d) Anchor cable pre-tightening of $300 \mathrm{kN}$

Fig. 14 Horizontal support stress fields with different anchor cable pre-tightening forces

support compressive stress zone, and a stress field of approx. $0.245 \mathrm{MPa}$ is generated in the anchor cable support compressive stress zone.
After the excavation of the air-return entry, the support effect of the rock bolts and anchor cables can produce a certain compressive stress in the lateral coal body. This reduces the tensile shear stress caused by the excavation and unloading, which develops the lateral coal body's stress state in a direction conducive to stability.

Different anchor cable support parameters lead to different stress fields, which in turn affect the mechanical parameters of the coal body. Increasing the control range and capacity of the anchor cables is conducive to the formation of a prestressed load-bearing structure with greater stiffness in the anchorage area. This may become the main bearing structure, thereby preventing the rock layer outside the anchorage area from separating and facilitating the maintenance of the air-intake entry roof.

\section{Analysis of support effect under mining influence}

In the case of ESSPL, the air-return entry is driven along the roof of the coal seam, which is equivalent to reducing the mining height of the seam. In addition, the trapezoidal bottom coal body left between the panels plays a certain role in protecting the air-intake entry of the successive panel. Thus, the external staggered distance should be less than that of the traditional gob-side entry. When the entry is driven along the goaf, there is typically no coal pillar (or at most a pillar of 3-5 $\mathrm{m}$ in width) left to block the gangue, water, or harmful gas in the goaf (Du and Meng 2014). In this paper, the external staggered distance between panels is set to $3.0 \mathrm{~m}$.

In mining scenarios using $2302 \mathrm{~S}$ panels, the superposition of the front abutment pressure and side abutment pressure will change the stress state of the gob-side entry, leading to an increase in the plastic area and roadway deformation. Considering the influence of mining processes in successive panels, the combined support effect of the external staggered gob-side entry was verified through numerical simulations.

The model covered a domain measuring $392 \mathrm{~m}$ (length) $\times 300 \mathrm{~m}$ (width) $\times 120 \mathrm{~m}$ (height), as shown in Fig. 15. The panel length along the strike was set to $110 \mathrm{~m}$ in consideration of the computation time of the model. The side boundaries were roller constrained and the bottom boundary was fixed both horizontally and vertically. A uniform stress of $800 \mathrm{~m} \times 0.025 \mathrm{MN} / \mathrm{m}^{3}=20 \mathrm{MPa}$ was applied to the top of the model, corresponding to $800 \mathrm{~m}$ of overburden strata, by assuming the overlying unit weight was $0.025 \mathrm{MN} / \mathrm{m}^{3}$. The rock mass engineering properties used for the numerical modeling are presented in Table 4 . The optimal side rock bolt and anchor cable support 
parameters of the air-return entry in ESSPL were determined in Sects. 4.5 and 5.4.

According to monitoring results for the abutment pressure distribution, the distance from the peak stress position to the coal wall of a working face is approx. $20 \mathrm{~m}$. Thus, after the mining of the 2301S panel had been completed, the $2302 \mathrm{~S}$ panel was excavated $150 \mathrm{~m}$. The plastic zone distribution $20 \mathrm{~m}$ in front of the working face around the external staggered gob-side entry was extracted, and the results are shown in Fig. 16.

The blue region in Fig. 16 indicates that no damage has occurred, i.e., this is an elastic zone. The red zone indicates that failure is currently occurring, i.e., the surrounding rock in the area is unstable in the current state. The green zone indicates that damage has occurred in the past, but is not ongoing. This suggests that, in the current state, the surrounding rock is relatively stable.

Due to the support effect of side bolts and anchor cables along the air-return entry, the roof of the air-intake entry in the combined support area has not been completely damaged. The red areas on the roof and sides of the air-intake are small, and most of the remaining area is green. Therefore, in the current stress state, there is little plastic failure of the surrounding rock, and the red areas are all within the control range of the rock bolts. The plastic depth in the middle of the air-intake entry roof is only $2.3 \mathrm{~m}$, and the maximum depth is $3.5 \mathrm{~m}$. The upper rock layer of the combined support area exhibits no plastic failure, and thus provides an effective anchor point for the roof rock bolts and anchor cables of the air-intake entry, preventing the plastic zone from further development and ensuring the stability of the roadway roof.

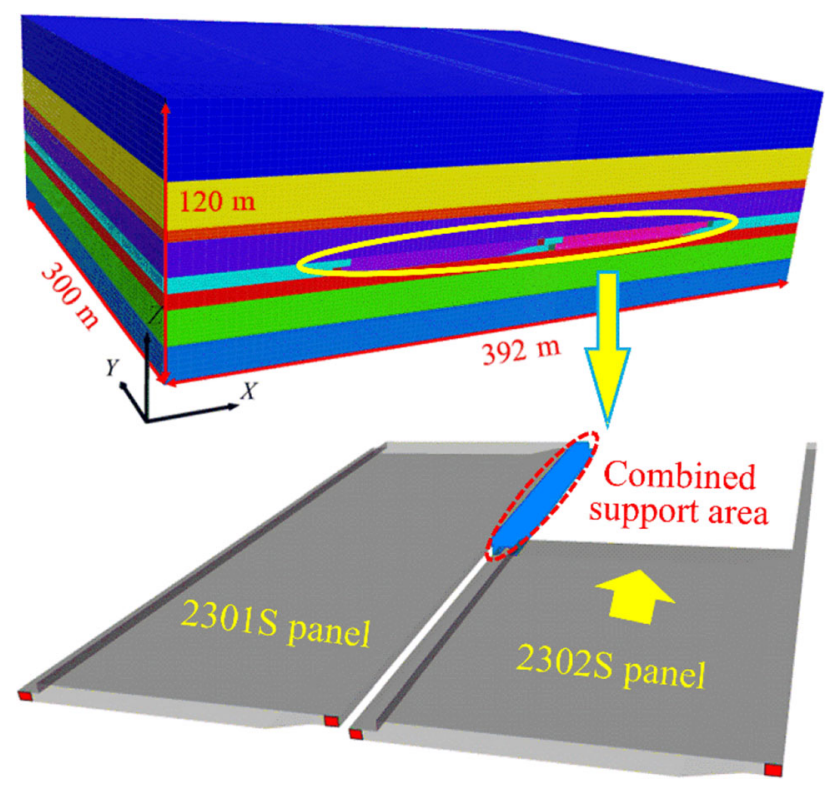

Fig. 15 Numerical modeling of ESSPL

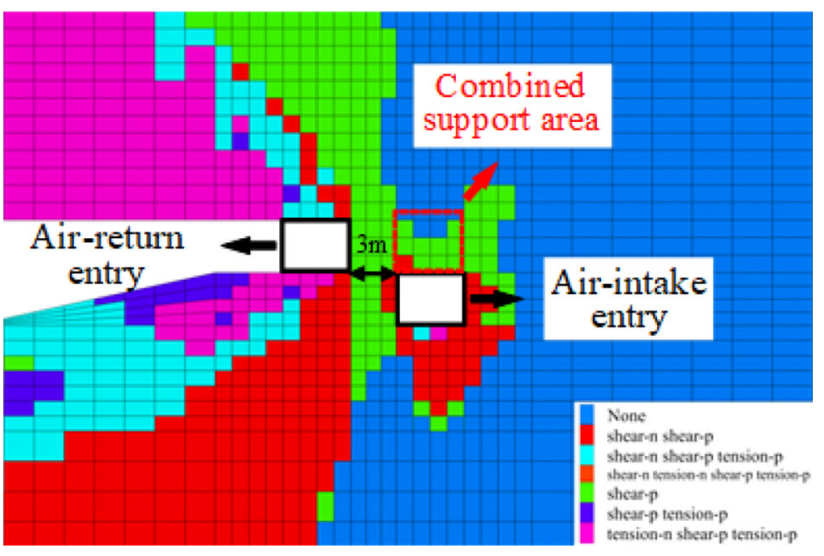

Fig. 16 Plastic zone distribution of gob-side entry

This analysis shows that, under the condition of ESSPL, the mechanical properties and stress state of the surrounding rock are improved by the anchoring effect of the side rock bolts and anchor cables of the air-return entry, which plays a positive role in protecting the coal body of the air-intake entry roof and side wall. The air-return entry is conducive to the stability of the side wall and the realization of the suspension effect of roof rock bolts and anchor cables, enhancing the surrounding rock maintenance of the gob-side entry of the thick coal seam.

\section{Conclusion}

(1) Using the spatial structure characteristics of ESSPL, a combined support technology for adjacent roadways was proposed, and its characteristics were summarized and analyzed.

(2) FLAC $^{3 \mathrm{D}}$ was used to analyze the influence of the rock bolt parameters on the mechanical properties of the anchorage body. The optimal values of the rock bolt support parameters were determined as follows: rock bolt spacing of $0.8 \mathrm{~m}$, rock bolt pre-tightening force of $80 \mathrm{kN}$, rock bolt diameter of $22 \mathrm{~mm}$, and rock bolt length of $3.0 \mathrm{~m}$. Under this support scheme, the uniaxial compressive strength of the anchorage body can be increased by $1.42 \mathrm{MPa}$, the shear strength increases by $1.98 \mathrm{MPa}$, the cohesion is increased by $0.168 \mathrm{MPa}$, and the internal friction angle increases by $3.77^{\circ}$. Thus, the technique of installing rock bolts into the coal body along the airreturn entry can improve the mechanical properties of the anchorage body, providing a mechanical basis for the roof support of the external staggered gobside entry.

(3) FLAC $^{3 \mathrm{D}}$ was used to analyze the influence of the anchor cable parameters on the support stress 
distribution of a lateral coal body. It was determined that an anchor cable length of $8.0 \mathrm{~m}$, anchor cable spacing of $1.0 \mathrm{~m}$, and anchor cable pre-tightening force of $250 \mathrm{kN}$ were optimal. Under this support scheme, the superposition effect between the rock bolt and anchor cable support parameters is obvious. A support compressive stress field of approx. 0.3 $\mathrm{MPa}$ can be formed in the rock bolt-anchor cable support compressive stress zone, and one of approx. $0.245 \mathrm{MPa}$ is generated in the anchor cable support compressive stress zone.

(4) Through the verification of the support effect under the influence of mining, it was found that, in the case of ESSPL, the support of the air-return entry side rock bolts and anchor cables improves the mechanical properties and stress state of the surrounding rock, which has a positive effect in protecting the coal body of the air-intake entry roof and side wall. Thus, the air-return entry is conducive to the stability of the side wall and the realization of the suspension effect for roof bolts and anchor cables, which makes the surrounding rock maintenance of the gob-side entry of the thick coal seam more favorable.

Acknowledgements This study was funded by the National Natural Science Foundation of Surface Project of China (Nos. 51774289; 52074291), the National Natural Science Foundation of the Youth Science Foundation of China (No. 51404270), the Fundamental Research Funds for the Central Universities (No. 2011QZ06), and the Open Fund of the State Key Laboratory of Coal Resources in Western China (No. SKLCRKF1903).

Authors' contributions Adrian Batugin and Zhiqiang Wang contributed to the conceptualization of the paper. Zhiqiang Wang conceived the technology. All authors were involved in designing and carrying out the numerical modeling studies. Zhiqiang Wang and Zehua Su wrote the paper. Adrian Batugin, and Shermatova Sayyora Sidikovna performed significant review and editing of the paper.

Funding The National Natural Science Foundation of Surface Project of China (Grant Nos. 51774289; 52074291). The National Natural Science Foundation of the Youth Science Foundation of China (Grant No. 51404270). The Fundamental Research Funds for the Central Universities (Grant No. 2011QZ06). The Open Fund of State Key Laboratory of Coal Resources in Western China (Grant No. SKLCRKF1903).

Availability of data and material All data generated or used during the study appear in the submitted article.Code availability Not applicable.

\section{Compliance with ethical standards}

Conflict of interest The authors declare that they have no conflicts of interest.
Open Access This article is licensed under a Creative Commons Attribution 4.0 International License, which permits use, sharing, adaptation, distribution and reproduction in any medium or format, as long as you give appropriate credit to the original author(s) and the source, provide a link to the Creative Commons licence, and indicate if changes were made. The images or other third party material in this article are included in the article's Creative Commons licence, unless indicated otherwise in a credit line to the material. If material is not included in the article's Creative Commons licence and your intended use is not permitted by statutory regulation or exceeds the permitted use, you will need to obtain permission directly from the copyright holder. To view a copy of this licence, visit http://creativecommons. org/licenses/by/4.0/.

\section{References}

Aghababaei S, Jalalifar H, Saeedi G (2019) Prediction of face advance rate and determination of the operation efficiency in retreat longwall mining panel using rock engineering system. Int J Coal Sci Technol 6(3):419-429. https://doi.org/10.1007/ s40789-019-0245-6

Du JP, Meng XR (2014) Mining science. China University of Mining and Technology Press, Xuzhou

Guo ZB, Wang Q, Yin SY, Kuai XH, Yan DS, Qu YD, Li MY (2019) The creep compaction behavior of crushed mudstones under the step loading in underground mining. Int $\mathrm{J}$ Coal Sci Technol 6(3):408-418

He MC, Guo ZB (2014) Mechanical property and engineering application of anchor bolt with constant resistance and large deformation. Chin J Rock Mech Eng 33(7):1297-1308

He FL, Zhang GC (2016) Deformation and failure mechanism and control technology of large section coal roadway subjected to severe mining dynamic load. J Min Saf Eng 33(3):423-430

He MC, Wang J, Sun XM, Yang XJ (2014) Mechanics characteristics and applications of prevention and control rock bursts of the negative Poisson's ratio effect anchor. J China Coal Soc 39(2):214-221

He FL, Bo YS, Xu ZH, Li EP, Xu L, Li TD (2015a) Research on stability of open-off cut surrounding rock with thick coal roof and its reasonable anchor cable configuration. J Min Saf Eng 32(2):233-239

He FL, Gao F, Sun YJ, Li SJ, Song BH, Yang YF (2015b) Multiplecable-girder-truss asymmetric support mechanism and its application in the roadway of fully mechanized top coal caving face with narrow coal pillar. J China Coal Soc 40(10):2296-2302

$\mathrm{He}$ MC, Li C, Gong WL (2015c) Elongation and impacting experimental system for bolts with constant resistance and large deformation and finite element analysis. Chin J Rock Mech Eng 34(11):2161-2178

Hou CJ, Li XH (2011) Stability principle of big and small structures of rock surrounding roadway driven along goaf in fully mechanized top coal caving face. J China Coal Soc 26(1):1-7

Ju Y, Zhu Y, Xie HP, Nie XD, Zhang Y, Lu C, Gao F (2019) Fluidized mining and in situ transformation of deep underground coal resources: a novel approach to ensuring safe, environmentally friendly, low-carbon, and clean utilisation. Int J Coal Sci Technol 6(2):184-196

Kang HP, Wang JH, Lin J (2007) High pretensioned stress and intensive bolting system and its application in deep roadways. J China Coal Soc 32(12):1233-1238

Kang HP, Wang JH, Lin J (2010a) Case studies of rock bolting in coal mine roadways. J China Coal Soc 29(4):649-664 
Kang HP, Wang JH, Lin J (2010b) Study and applications of roadway support techniques for coal mines. J China Coal Soc 35(11):1809-1814

Li L, Bai JB, Wang XY (2012) Rational position and control technique of roadway driving along next goaf in fully mechanized top coal caving face. J China Coal Soc 37(9):1564-1569

Lu W, Wang Q, Jiang B, Xu S, Liu BH, Zhang P, Jiang ZH (2019) Comparative study on bearing mechanism and design parameters of confined concrete arch joints in deep soft rock roadway. Int $\mathrm{J}$ Coal Sci Technol 6(4):493-504

Ma NJ, Zhao ZZ, Feng JC (2013) Technology of butt long bolt on roadway supporting in difficult conditions. Coal Sci Technol 41(9):117-121

Ma NJ, Zhao XD, Zhao ZZ, Li J, Guo XF (2015) Stability analysis and control technology of mine roadway roof in deep mining. J China Coal Soc 40(10):2287-2295

Wang ZQ (2016) Combined support technology of adjacent roadways for gob-side entry driving in Thick Coal Seams. China Patent 201610547374.7, 12 July

Wang JH, Kang HP, Gao F (2008) Numerical simulation on loadtransfer-mechanisms and stress distribution characteristics of cable bolts. J China Coal Soc 33(1):1-6

Wang HS, Zhang DS, Li SG, Wang L, Wu LZ (2014) Rational width of narrow coal pillar based on the fracture line location of key rock B in main roof. J Min Saf Eng 31(1):10-16
Wang ZQ, Qiao JY, Wu C, Song ZY, Shen C, Yin QH, Zhao JL (2019) Study on mine rock burst prevention and control technology based on gateway layout with negative coal pillars. Coal Sci Technol 47(1):69-78

Wang ZQ, Guo L, Su ZH, Wang SS, Shen C (2020a) Layout and combined support technology of alternate exterior stagger arrangement roadway and adjacent roadways in inclined and medium-thick coal seam. J China Coal Soc 45(2):542-555

Wang ZQ, Shi L, Wang P, Wu C (2020b) A novel gob-side entry method in China: a case study. Geotech Geol Eng 38:215-226

Xie HP, Gao F, Ju Y (2015) Research and development of rock mechanics in deep ground engineering. Chin J Rock Mech Eng 34(11):2161-2178

Zhang GC, Wu T, Wu JL, Dai DS, Shen SB, Zhao RB (2019) Mechanism and control technology of top coal squeezing and fracture of gob-side entry driving in fully-mechanized caving mining face. Coal Sci Technol 47(5):95-100

Zhao JL (2014) Development and outlook of 3-D stagger arrangement roadway layout technology. Coal Eng 46(1):1-3

Zhao JL, Li B (1998) A study on raising the recovery ratio of fullymechanized coal-talking about stagger-position-roadway-arrangement system. J Liaoning Tech Univ (Nat Sci) 17:237-239

Zuo JP, Wang JT, Jiang YQ (2019) Macro/meso failure behavior of surrounding rock in deep roadway and its control technology. Int J Coal Sci Technol 6(3):301-319 